\title{
Environmental Assessment of 9 European Public Bus Transportation Systems
}

\section{E. A. Nanaki ${ }^{1}$, C. J. Koroneos ${ }^{1}$, J.Roset ${ }^{2}$, T.Susca ${ }^{3}$, T. H. Christensen ${ }^{4}$, S. De Gregorio Hurtado ${ }^{5}$,A. Rybka $^{6}$,J.Kopitovic ${ }^{7}$, O.Heidrich $^{8}$, P.Amparo López-Jiménez ${ }^{9}$}

\author{
${ }^{1}$ University of Western Macedonia, Department of Mechanical Engineering, Bakola and Sialvera, 50100 Kozani, Greece, E-mail: \\ evananaki@gmail.com; koroneos@aix.meng.auth.gr \\ ${ }^{2}$ Departament de.Física Aplicada. ETS Arquitectura Barcelona Universitat Politecnica de Catalunya Avda. Diagonal, 64908028 Barcelona, \\ E-mail:Jaime.roset@upc.edu \\ ${ }^{3}$ Bundesanstalt für Materialforschung und -prüfung (BAM), Division 7.1 - Building Materials. Unter den Eichen, $87 \cdot 12205$ Berlin \\ Germany, Email: tiziana.susca@gmail.com \\ ${ }^{4}$ Danish Building Research Institute, Aalborg University, A. C. Meyers Vænge 15, 2450 Copenhagen SV, Denmark, E-mail: thc@sbi.aau.dk \\ ${ }^{5}$ CEDEX, Ministerio de Fomento C/ Alfonso XII, 3 y 528014 Madrid \\ Email: $\underline{\text { degregorio@mailpersonal.com }}$ \\ ${ }^{6}$ Faculty of Civil and Environmental Engineering, Department of Town Planning and Architecture, Rzeszow University of Technology. \\ Poland, Email: akbyr@prz.edu.pl \\ ${ }^{7}$ Head of department, Software Engineering Transport and Telecommunication, Lomonosova Street, 1 \\ Riga, Latvia ,Email: kopitovs.j@tsi.lv \\ ${ }^{8}$ Senior Researcher at the School of Civil Engineering \& Geosciences and Research Fellow with the Tyndall Centre for Climate Change \\ Research, Newcastle University, Newcastle upon Tyne, NE1 7RU, U.K.; Tel: +44 191222 6563; Fax: + 44191222 6669; \\ Oliver.heidrich@ncl.ac.uk \\ ${ }^{9}$ Hydraulic and Environmental Engineering Department, Universitat Politècnica de València, Camino de Vera s/n. 46022. Valencia. Spain, \\ Email: palopez@upv.es

\section{Abstract} \\ The transportation sector is one of the largest sources of EU's greenhouse gas emissions. In 2011, \\ transportation represented approximately 25 percent of total EU's greenhouse gas emissions. Urban mobility \\ accounts for $40 \%$ of all $\mathrm{CO}_{2}$ emissions of road transport and up to $70 \%$ of other pollutants from transport. As, \\ transportation and mobility play a crucial part both in urban economics and the quality of life, it is of great \\ significance to ensure a low carbon transportation sector, so as to deal with the threat that climate change \\ poses to urban areas. This study examines the factors that affect the production of carbon dioxide $\left(\mathrm{CO}_{2}\right)$ as well \\ as of air pollutants, in 9 major European cities, aiming to provide a comprehensive overview of the actual \\ knowledge on the atmospheric pollution from public transportation systems. $\mathrm{CO}_{2}$ emissions as well as air \\ pollutants, such as $\mathrm{CO}, \mathrm{HC}, \mathrm{PM}, \mathrm{NOx}$ are calculated for the diesel and CNG bus fleets of the European cities \\ under study. Finally the environmental benefits, in terms of $\mathrm{CO}_{2}$ and $\mathrm{CO}, \mathrm{HC}, \mathrm{PM}, \mathrm{NOx}$ emissions reductions, \\ from the penetration of different biodiesel blends (from B10 to B100) to the bus fleets are estimated.
}

Keywords: urban buses; air pollution; urban transportation 


\section{Introduction}

In 2009, $\mathrm{CO}_{2}$ emissions, from the transportation sector increased, with over $50 \%$ of those emissions coming from passenger vehicles [1]. Since 1990, greenhouse gas emissions (GHG) from the transport sector in the EU have grown considerably and they are projected to continue increasing [2]. Public transportation systems play a crucial role to cities, as they are responsible for the mobility and access to most activities; nonetheless the transition to a low carbon public transportation system is challenging. In this context, cities lay out the path for $\mathrm{CO}_{2}$ mitigation, showing the way to a low carbon public transportation system. Especially in the case of European cities that encounter problems originated from transport and traffic, the challenge is to improve mobility whilst at the same time reducing the use of fossil fuels, traffic congestion and air pollution. Alone in the UK some 30000 deaths were linked to air pollution in 2008 - with 4000 in London alone [3].

As per National Strategic Reference Frameworks, which was submitted by EU Member States, the sustainable urban transport is a key area to be examined [4]. The upgrading of public transport services in conjunction with affordable transportation fares seems to be a cost-effective measure for fuel savings and emissions reductions from urban transportation. In this context and in line with the objectives set by the European Commission's White Paper on transport, the European Union has adopted specific policy targets for transport [5]. The White Paper sets the target of achieving a $60 \%$ reduction in greenhouse gas emissions (GHG) from transport by 2050 compared to 1990 levels. This target represents the contribution of the transport sector to the overall EU objective of a 80-95\% reduction of its GHG as stated in the Roadmap for a low carbon economy by 2050 [6].

The environmental impacts caused by public transportation systems, and especially by buses, have been extensively studied, including inter alias the studies of Ally and Pryor [7], Beer et al. [8],Caulfield and Ryan [9], Sheehan et al., [10], Oua et al. [11].

This study intends to demonstrate the necessary steps that need to be taken, so as to increase the attractiveness of public transport leading to a low carbon public transportation system. This study aims to assess the sustainability of public transportation systems in nine European cities. This should help policy makers and other parties involved in $\mathrm{CO}_{2}$ emission reduction to review current policies and define new, effective policy measures. The positions of the cities under study with respect to long term sustainability issues such as pollutant emissions and GHG are assessed. Although the main focus is on the improvement of air quality, other drivers affecting the sustainability of the public transportation sector -such as the impact of economic growth and the ticket prices are also considered. The majority of bus fleets in the cities under study uses conventional diesel fuel with some contribution from natural gas buses.

\section{Methods}

The methodology used for the estimation of emissions takes into consideration the exhaust emissions of $\mathrm{CO}$, $\mathrm{NOx}, \mathrm{CO}_{2}, \mathrm{PM}$ and $\mathrm{HC}$ for each vehicle technology of the nine European cities bus fleets. Since, PM mass emissions in vehicle exhaust mainly fall in the PM2.5 size range, all PM mass emission factors are assumed to correspond to PM2.5. The fuel used by different vehicle categories as well as their emission standards are taken into consideration. In this context, the vehicle category of buses includes urban CNG buses and urban diesel buses according to emission-control legislation categories (EUROI, II, III, IV, V, VI). The technical data used take into account national variations.

The parameters that the variations include inter alias are: fuel consumption, composition of vehicle park, vehicle age, driving patterns, some fuel parameters and climatic conditions. Other variations which may exist, e.g. variations in vehicle maintenance, are not accounted for, because there is not enough data available to do 
so. The calculation is based on the following main types of input parameters: total fuel consumption, vehicle technology, vehicle park, driving condition, emission factors.

The emission factors are stated in units of grammars per vehicle-kilometer for each vehicle technology. These average European emission factors are determined using typical values for driving speeds, ambient temperatures, highway-rural-urban mode mix, trip length, etc. [12]. Based on the above and in order to calculate the emissions of each vehicle technology, the following equation is used:

$$
E i, j=\sum k(N j, k \times M j, k \times E F i, j, k)
$$

where, $j$ are the vehicle categories of diesel and CNG buses, $\mathrm{k}$ is the technology of each category (i.e. EURO I, EURO II, etc), $\mathrm{Nj}, \mathrm{k}$ is the number of vehicles in the city's under sturdy bus fleet of category $j$ and technology $k$ $\mathrm{Mj}, \mathrm{k}$ represents the average annual distance driven per vehicle of category $j$ and technology $k, E F i, j, k$ represents the technology-specific emission factor of pollutant $i$ for vehicle category $j$ and technology $k$.

The emissions factors used are obtained from the studies of Beer et al [13] as well as of Nylund et al, [14]. Table 1 presents the emissions factors used for the diesel bus fleet; whereas Table 2 presents the emissions factors used for the CNG bus fleet. Data regarding the metropolitan areas characteristics as well as the bus transport networks refer to year 2010.

\begin{tabular}{|c|c|c|c|c|c|}
\hline ENGINE TYPE & $\mathrm{CO}_{\mathbf{2}} \mathbf{g r} / \mathbf{k m}$ & $\mathbf{C O} \mathbf{~ g r} / \mathbf{k m}$ & $\mathbf{H C} \mathbf{g r} / \mathbf{k m}$ & $\mathbf{P M} \mathbf{~ g r} / \mathbf{k m}$ & $\mathbf{N O x} \mathbf{~ g r} / \mathbf{k m}$ \\
\hline EURO I & 1.397 & 1,50 & 0,3 & 0,45 & 16 \\
\hline EURO II & 1.386 & 1,35 & 0,2 & 0,2 & 14 \\
\hline EURO III & 1.351 & 1,00 & 0,15 & 0,18 & 9 \\
\hline EURO IV & 1.343 & 0,95 & 0,09 & 0,06 & 6,38 \\
\hline EURO V & 1.330 & 0,74 & 0,06 & 0,01 & 3,83 \\
\hline
\end{tabular}

Table 1. Emissions factors for diesel bus fleet

It is noted that emission data for the city of Copenhagen are calculated by Movia (the company responsible for bus transport in Copenhagen) on the basis of Movia's own emission model, which takes into account the specific composition of types of busses (including busses with/without filters/catalysts etc.). The data has been provided to the authors by Movia through personal communication. The data represents the basis for the annual "Green accounts" of Movia.

\begin{tabular}{|c|c|c|c|c|c|}
\hline ENGINE TYPE & $\mathrm{CO}_{2} \mathbf{g r} / \mathbf{k m}$ & $\mathrm{CO} \mathbf{g r} / \mathbf{k m}$ & $\mathrm{HC} \mathbf{~ g r} / \mathbf{k m}$ & $\mathrm{PM} \mathrm{gr} / \mathbf{k m}$ & $\mathbf{N O x} \mathbf{~ g r} / \mathbf{k m}$ \\
\hline EURO I & 1.100 & 2,70 & 4,7 & 0,01 & 15 \\
\hline EURO II & 1.250 & 1,00 & 1,33 & 0,01 & 10 \\
\hline
\end{tabular}

Table 2. Emissions factors for CNG bus fleet

3. Metropolitan Areas Characteristics

The cities under study are located in Europe and have some similarities as well as differences (Table 3). The areas are very heterogeneous in every socio-economic aspect considered. For instance, in terms of population, the foremost inhabited region is the capital of Spain with over 5 million people (Madrid- 6,458,684) whereas Rzeszow is the least $(181,204$ inhabitants). Barcelona has the second greatest number of inhabitants (5,010,000 inhabitants) followed by Athens (4,376,208 inhabitants) and Valencia (1,800,031,220 inhabitants). During the past decade the population of Barcelona has declined, contrary to marked demographic increases in the wider metropolitan area [15]. 


\begin{tabular}{|c|c|c|c|c|c|c|}
\hline COUNTRY & CITY & $\begin{array}{c}\text { Population } \\
\text { (inhabitants) }\end{array}$ & $\begin{array}{l}\text { Area } \\
\left(\mathrm{km}^{2}\right)\end{array}$ & $\begin{array}{c}\text { Density } \\
\left(\text { inha/ } \mathbf{k m}^{2} \text { ) }\right.\end{array}$ & $\begin{array}{l}\text { Annual } \\
\text { GDP (€) }\end{array}$ & $\begin{array}{c}\text { Unemployment } \\
\text { Rate (\%) }\end{array}$ \\
\hline Greece & Athens & $4,376,208$ & 1,450 & 5,882 & 19,997 & 20.9 \\
\hline Spain & Barcelona & $5,010,000$ & 3,239 & 1,547 & 30,000 & 20.5 \\
\hline Italy & Bari & 320,146 & 2,270 & 2,758 & 19,600 & 12.1 \\
\hline Denmark & Copenhagen & 528,208 & 90 & 5,883 & 57,661 & 7.9 \\
\hline Spain & Madrid & $6,458,684$ & 8,026 & 804,72 & 28,850 & 21.3 \\
\hline UK & Newcastle & $1,093,000$ & 538,00 & 2,081 & 20,046 & 7.0 \\
\hline Latvia & Riga & 706,413 & 304,05 & 2,323 & 14,097 & 9.1 \\
\hline Poland & Rzeszow & 181,204 & 116.56 & 1,554 & 9,740 & 7.8 \\
\hline Spain & Valencia & $1,800,031$ & 1,415 & 1,272 & 20,259 & 24.7 \\
\hline
\end{tabular}

Table 3. Basic socioeconomic data of urban areas -2010 [13-34]

Concerning the surface area, Madrid has the biggest area $\left(8,026 \mathrm{~km}^{2}\right)$, then Barcelona $\left(3,239 \mathrm{~km}^{2}\right)$ and Bari $\left(2,270 \mathrm{~km}^{2}\right)$, while Rzeszow with an area of $116.56 \mathrm{~km}^{2}$ presents a low level of urbanization due to its city boarders change during the period of 2006 - 2010. Athens and Bari in terms of surface area are densely populated (5,882 and 2,758 people per square kilometre). Madrid and Barcelona have in common the significant disperse urban development, which took place during the past decade and was accompanied by increased land consumption.

With regards to the economic figures, the average annual GDP per capita in the cities is $24,472 €$, with great differences from Copenhagen (57,661 €/inhabitant-year) to Rzeszow (9,740 €/inhabitant-year). Unemployment rates are also associated with the economic structure of each city. The Spanish areas show high score $(24.7 \%$ in Valencia, 21.3\% in Madrid, 20.5\% Barcelona), followed by Athens (20.9\%). On the other side, Copenhagen with only $6.5 \%$ and urban area of Newcastle with $7 \%$ have the lowest unemployment rates of the areas among the available data. These data are closely linked to the economic structure in each city, but there can be differences in comparison coming from different labor legislation.

\section{Bus Transport Networks}

The urban areas under examination have dense bus networks. Madrid and Barcelona are the cities with the greatest number of bus lines with 693 and 692 lines respectively. Likewise Athens and Newcastle have more than 300 lines as whole network. Table 4 outlines the distinctive qualities of the bus networks under study.

\begin{tabular}{|l|c|c|c|c|c|c|}
\hline & $\begin{array}{c}\text { Length of } \\
\text { Bus } \\
\text { Network } \\
(\mathbf{k m})\end{array}$ & $\begin{array}{c}\text { Bus } \\
\text { Lines }\end{array}$ & Passengers per year & Buses & $\begin{array}{c}\text { Number of } \\
\text { Operators } \\
\text { Public } \\
\text { Private }\end{array}$ \\
\hline Athens & 8,500 & 319 & $421,080,000$ & 2,151 & 1 & - \\
\hline Barcelona & 28,705 & 692 & $263,300,000$ & 2,318 & 1 & 42 \\
\hline Bari & 554 & 71 & $25,369,562$ & 235 & 1 & - \\
\hline Copenhagen & N/A & 67 & $88,000,000$ & N/A & 1 & \\
\hline Madrid & 25,916 & 693 & $423,409,691$ & 4,216 & 3 & 31 \\
\hline Newcastle & 860 & 339 & $143,000,000$ & 1,104 & 1 & 3 \\
\hline Riga & 1,817 & 53 & $62,174,292$ & 476 & 1 & - \\
\hline Rzeszow & 657 & 46 & $13,080,000$ & 156 & 1 & - \\
\hline Valencia & $3,909.9$ & 108 & $90,157,382$ & 2,281 & 1 & 8 \\
\hline
\end{tabular}

Table 4. Characteristics of bus transport networks under study -2010 [13-34] 
The length of the urban bus networks on average reaches $8,768.76 \mathrm{~km}$. The bus networks of Barcelona and Madrid are the biggest, coming up to $28,705 \mathrm{~km}$ and $25,916 \mathrm{~km}$ respectively. Athens and Valencia follow with $8,500 \mathrm{~km}$ and $3,909 \mathrm{~km}$. With regards to bus fleets, the average number of buses of the cities under study is 1,660 with great differences. The bus fleet of the city of Madrid comprises of 4,216 vehicles having an average age of 6.1 years. The bus fleets of Barcelona, Valencia and Athens follow with 2,318; 2,281 and 2,151 buses respectively and an average age of 9 years. Newcastle follows with 1,104 buses. The bus fleet of Bari comprises of 235 buses (average age of 8 years); whereas the bus fleet of Rzeszow comprises of 156 buses (average age of 15 years).

In some cities one single company operates the urban lines. This is the case for example of Athens (over 300 lines), Bari (71 lines) and Rzeszow (46 lines). ETHEL S.A. (member of the OASA, who is the shareholder of Public Transport Operators) operates the buses that serve the capital of Athens. Azienda Mobilità e Trasporti Bari S.p.A. (AMTAB) operates the buses that serve Bari. Transports Metropolitans de Barcelona (TMB) operates two transport networks (bus and underground metro) serving the city of Barcelona; whereas the whole Region of Madrid (Comunidad de Madrid) is served by a network of public transport managed by the Madrid Transport Authority (Consorcio Regional de Transportes de Madrid -CRTM-) [26]. Overall the demand for bus transport in Barcelona rose $0.6 \%$ compared to 2010 [25]. Copenhagen's bus network is managed by the public transport agency Movia, and is an integrated part of the Greater Copenhagen bus system; bicycling and walking dominate in the City of Copenhagen (67\% of all trips), and only $8 \%$ of the trips happens by bus [21].Bus services in Newcastle are predominantly run by commercial operators (Arriva, Go North East and Stage Coach)as well as by Nexus, which includes $10 \%$ of the bus network [28]. It is noted that in Newcastle catchment area $77 \%$ of total public transport journeys are made by bus.

The buses in Madrid and Athens transported more than 400 million passengers in 2011; whereas in Barcelona more than 200 million, in Newcastle more than 100 million and in Copenhagen about 90 million. The smallest number of passengers has been recorded for the city of Rzeszow (around 13 million) and is mainly attributed to the low quality of service. It is noted that in Rzeszow the number of passengers of public transport decreased from about 43 million to 36 million a year, from 2004 to 2010.

\section{Diesel and CNG Bus Fleets}

The air pollution and the environmental burdens of diesel-fuelled buses have been examined in a large body of literature. It has been shown that diesel-fuelled buses are responsible for pollutants emissions such as carbon dioxide $\left(\mathrm{CO}_{2}\right)$, carbon monoxide $(\mathrm{CO})$, sulphur dioxide $\left(\mathrm{SO}_{2}\right)$, sulphates $\left(\mathrm{SO}_{4}\right)$, nitrogen oxides (NOx), particulate matter $\left(\mathrm{PM}_{2.5}\right.$ and $\left.\mathrm{PM}_{10}\right)$ and volatile organic compounds (VOCs). The above mentioned air pollutants play a significant role to smog formation and have been associated with heart disease, respiratory illnesses, as well as premature death [37-40].

In 2010 diesel buses in the European cities under study with EURO III engine technology emitted 900,646 tons of $\mathrm{CO}_{2}$ whereas EURO $\mathrm{V}$ engine technology buses emitted 49,628 tons of $\mathrm{CO}_{2}$ (Fig. 1). As the engine technology improves (EURO I to EURO V) the emitted $\mathrm{CO}_{2}$ per kilometer driven is reduced. As far as the diesel-engine vehicles are concerned, the emissions are associated with the type of engine technology. For instance, air emissions are greater for Euro II vehicles compared to EURO III, EURO IV and EURO V. Not all cities have the same diesel technology buses. For instance EURO I engine technology is available in Athens, Rzeszow, Newcastle and Valencia; whereas EURO V vehicle technology is not available in Bari and Rzeszow. 


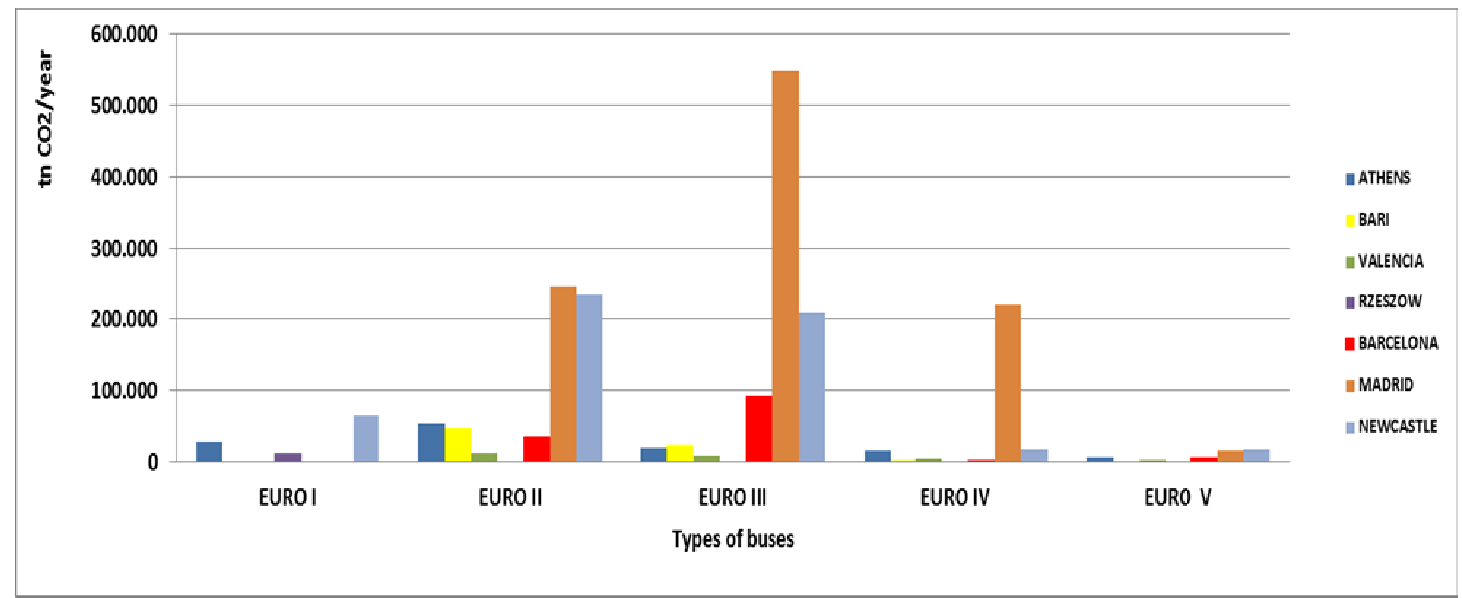

Fig. 1. $\mathrm{CO}_{2}$ emissions per diesel engine type in 2010

In terms of $\mathrm{CO}_{2}$ emissions the cities of Madrid and Newcastle have the highest diesel buses' emissions $\left(1,028,422\right.$ and 543,109 tons of $\left.\mathrm{CO}_{2}\right)$ followed by the cities of Barcelona and Athens with 134,893 and 125,467 tons of $\mathrm{CO}_{2}$ respectively. The city with the lowest $\mathrm{CO}_{2}$ emissions (12,170 tonnes) is Rzeszow (Fig. 2).

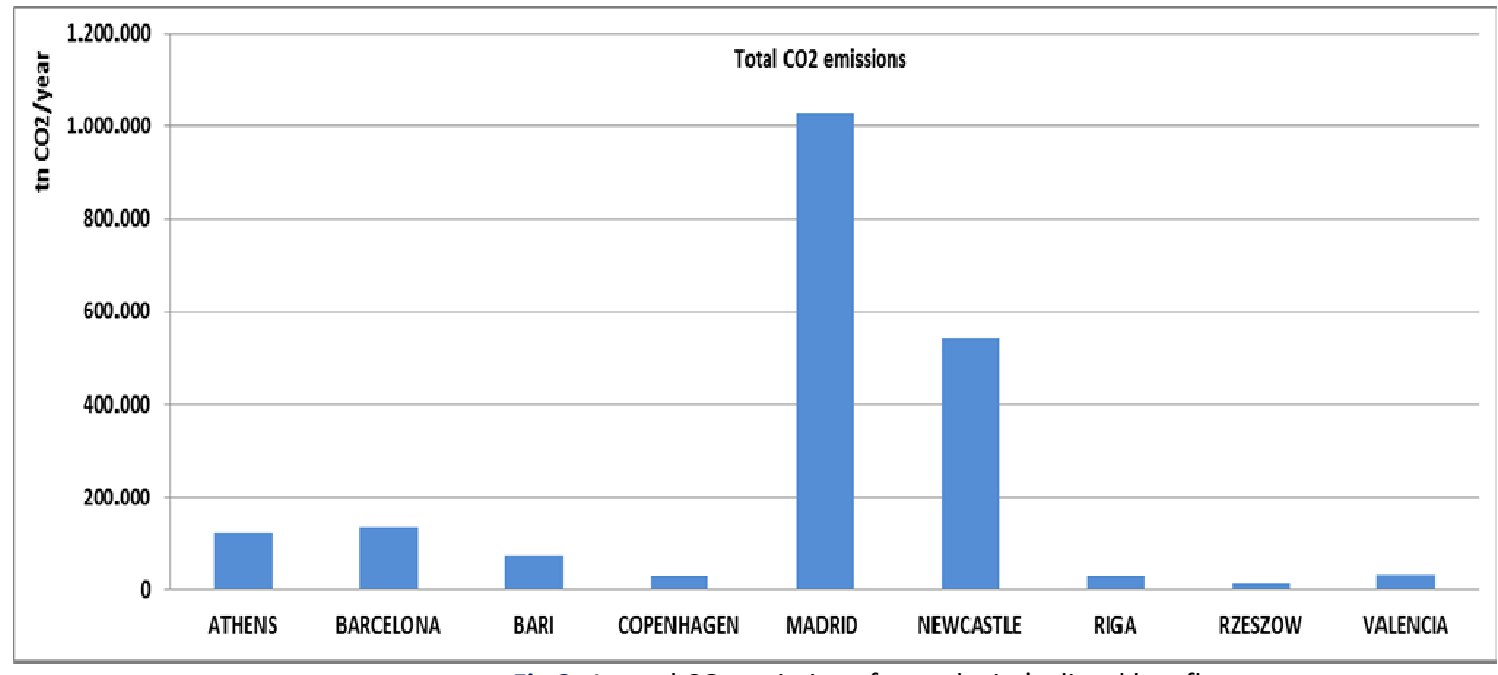

Fig 2. Annual $\mathrm{CO}_{2}$ emissions for each city's diesel bus fleet

It is obvious that as the engine technology improves (EURO I to EURO V) the emissions of $\mathrm{NO}_{\mathrm{x}}, \mathrm{PM}, \mathrm{CO}$ and $\mathrm{HC}$ resulting from the diesel buses are significantly reduced (Fig. 3-6). Madrid and Barcelona in terms of CO emissions are the cities with the highest diesel buses' emissions (661and 151 tonnes of $\mathrm{CO}$ ) followed by the cities of Newcastle and Athens with 130 and 113 tonnes of CO respectively. The city with the lowest CO emissions (13 tonnes) is Rzeszow (Fig. 3-4). 


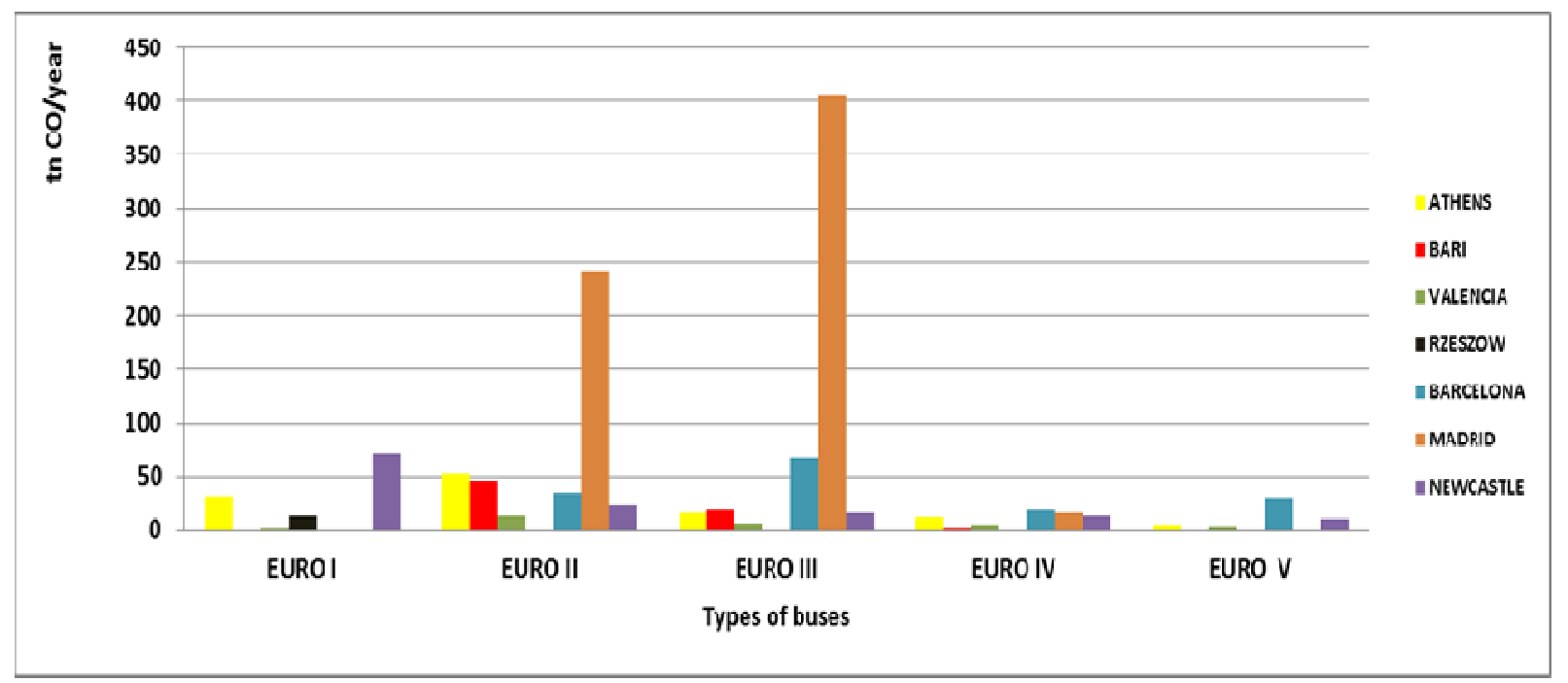

Fig 3. CO emissions per diesel engine type in 2011

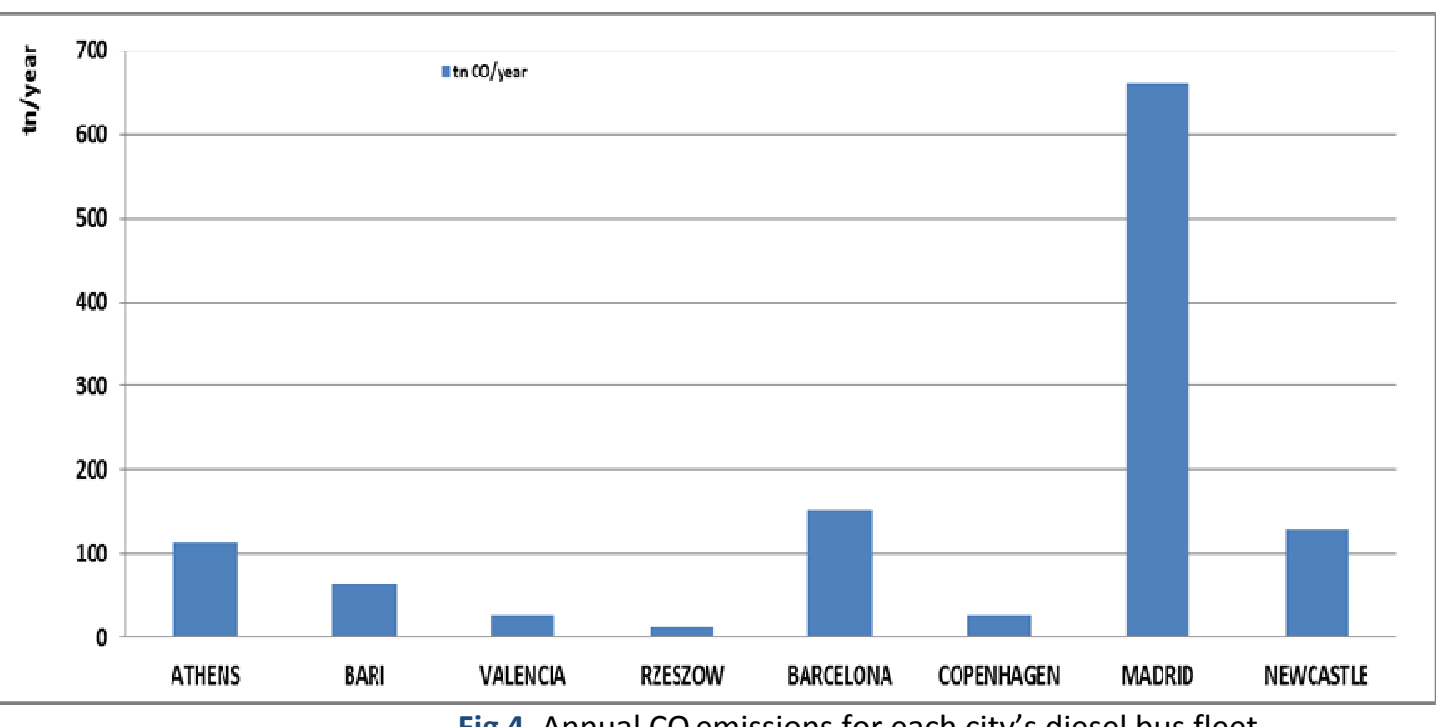

As Riga's bus fleet consists only of EURO II engine vehicles, the city appear to have the highest concentration of NOx emissions (3,832 tonnes of NOx) followed by Newcastle with 1,984 tonnes of NOx, Athens with 1,105 tonnes of NOx, Madrid with 722 and Bari with 647 tonnes of NOx (Fig. 5). Figure 6 illustrates that Madrid has the highest concentration of $\mathrm{HC}$ emissions with 111 tones followed by Barcelona with 20 tonnes of $\mathrm{HC}$, Athens with 18 tones and Bari with 10 tons; whereas in terms of PM emissions Athens and Madrid have the highest concentrations with 21 tons and 12 tons respectively. 


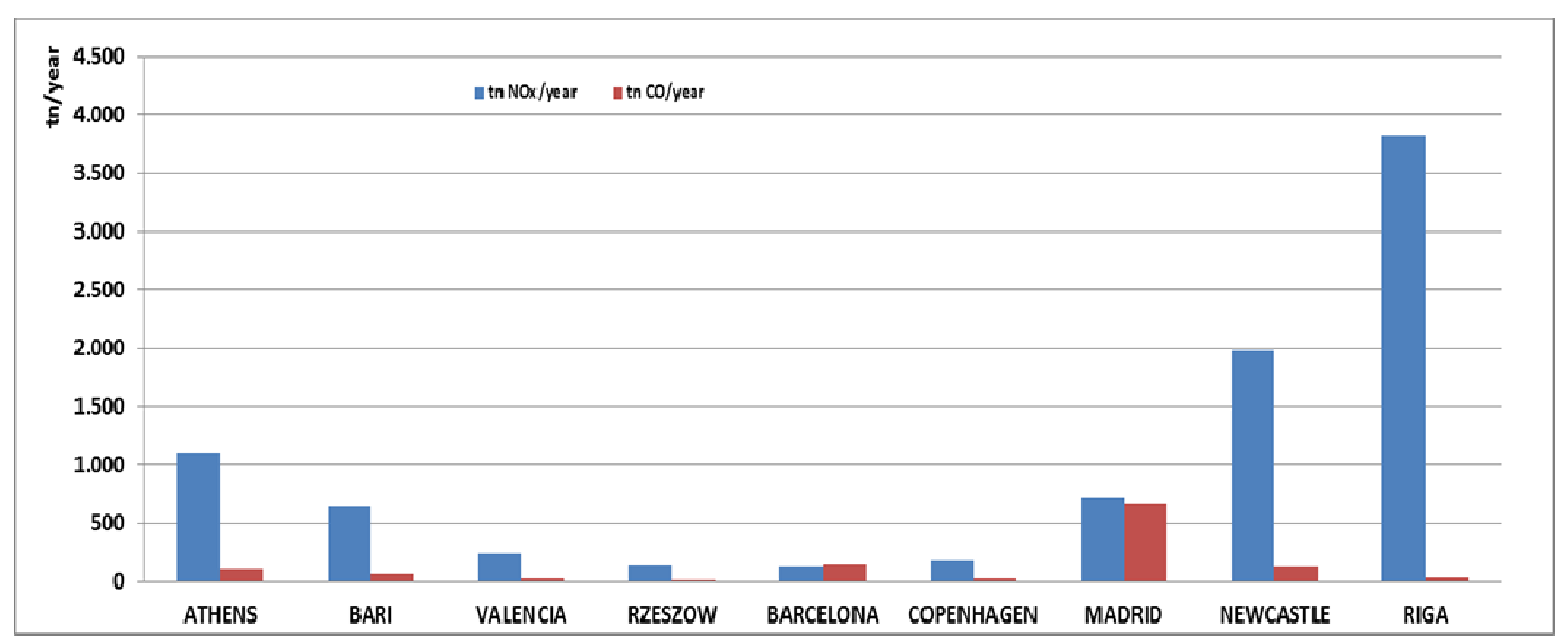

Fig 5. Annual NOx and CO emissions for each city's diesel bus fleet

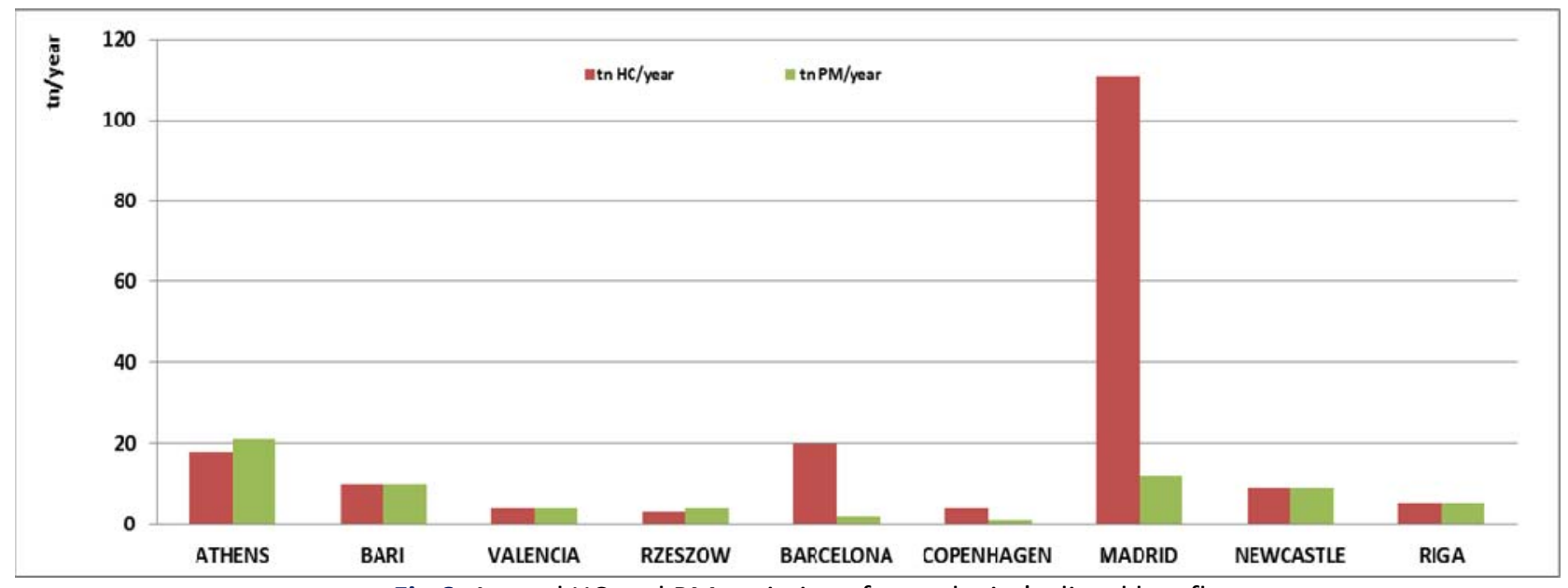

Fig 6. Annual HC and PM emissions for each city's diesel bus fleet

Not all of the cities under study have a CNG bus fleet. Athens, Bari, Barcelona and Rzeszow appear to have CNG bus fleets. Figure 7 illustrates the emissions from CNG bus technologies in each city. It is noted that from the cities under study only the cities of Athens, Barcelona, Bari, Madrid and Rzeszow have CNG buses. In this context, the city with the highest concentration of $\mathrm{HC}$ resulting from CNG bus fleet is the city of Barcelona followed by Madrid and Rzesow; this is attributed to the fact that the available CNG technology in these cities is EURO II engine vehicle. 


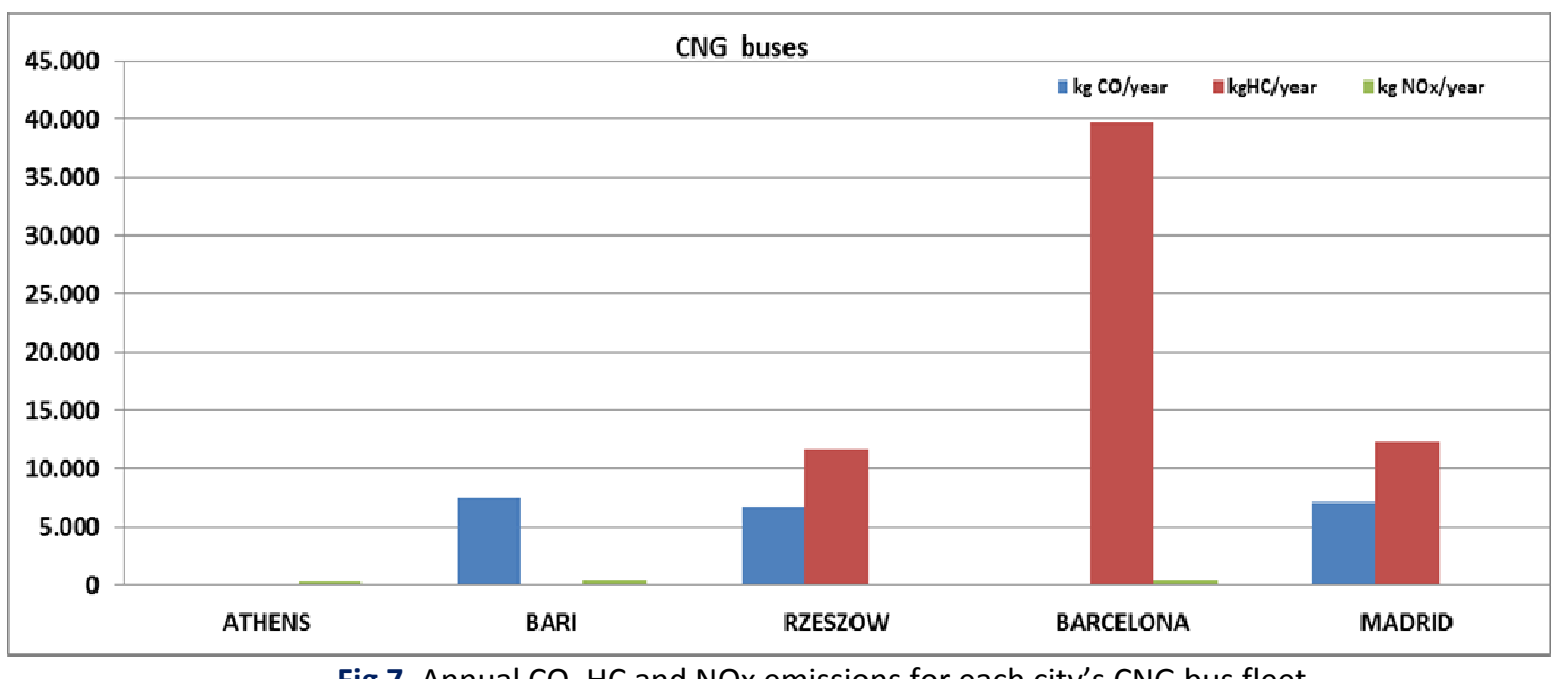

Fig 7. Annual $\mathrm{CO}, \mathrm{HC}$ and NOx emissions for each city's CNG bus fleet

The use of CNG engine buses leads to an important decrease in NOx emissions compared to the use of diesel engine buses. The emitted by CNG engines mass of particles is approximately 10 times lower compared to diesel engines (EURO II). The observed declining trends in newer Euro CNG engines emission standards go along with NOx and PM emissions; nonetheless not all bus models follow this general trend. It is noted that Barcelona has the highest emissions of $\mathrm{HC}(39,700 \mathrm{~kg}$ per year); followed by Madrid (12,359 kg per year) and Rzeszow (11,698 kg per year). The highest concentration of HC emissions in Barcelona can be attributed to the fact that the CNG bus fleet consists of EURO II vehicle technology.

\section{Biodiesel Use in Bus Fleets}

The use of biofuels aiming at EU's oil imports reduction as well as at GHG emissions mitigation has been promoted by many European Directives. These Directives include among others:

- EU Biofuels Directive 2003/30/EC promoting mandatory incorporation of biofuels inroad transport fuels (5.75\% energetic base in 2010).

- $\quad$ Fuel Quality Directive (2009/30/EC) obliging Member States to reduce carbon intensity of transport fuels by $6 \%$ by 2020 . The Fuel Quality Directive sets a target for a $6 \%$ reduction (compared to 2010 levels) of the GHG intensity of transport fuels supplied in the European Union. This reduction should be achieved through the use of alternative fuels.

Given that more than $98 \%$ of EU's transport sector relies on fossil fuels, biofuels might have a role to play to reduction of energy dependency and climate change mitigation. Until now conventional diesel buses have dominated the market, with some contribution from natural gas buses. As the technology options are increasing rapidly and various biofuels are offered as blending components for urban buses, the investigation of the potential benefits from the use of different biodiesel blends in the bus fleets of the cities under study, can play a significant role for a sustainable public transportation system.

In this context, five alternative biodiesel blends that can be used in the urban buses of the cities under study are assessed, using as data input the calculated emissions presented in previous section. The biodiesel blends, under study, range between $10 \%$ to $100 \%$ biodiesel and $90 \%$ to $0 \%$ diesel (B10, B30, B50, B80 and B100). The use of biodiesel in conventional diesel engines has a downward trend in tailpipe emissions. The emission abatement for engines manufactured before 2010, increases along with the percentage of biodiesel blends (from $10 \%$ to $100 \%$ ). Concerning the engines manufactured in 2010 , these have to meet the same emissions standards, regardless of the fuel (diesel, biodiesel, natural gas). 
Fig. 8 is illustrative of the $\mathrm{CO}_{2}$ benefits that $\mathrm{B} 100$ provides, resulting to lower $\mathrm{CO}_{2}$ emissions at a percentage of $78.45 \%$ (compared to equivalent diesel emissions). The use of B100 to the public buses of the cities of Madrid, Barcelona, Riga and Athens, which have the highest concentrations of diesel $\mathrm{CO}_{2}$ emissions, could be beneficial for a low carbon transportation system. Lower-level blends, such as B80, also provide benefits, as B80 seems to reduce PM emissions approximately 59\% compared to equivalent diesel emissions; whereas B20 reduces PM emissions 10\% (Fig. 9). The cities of Athens, Madrid, Bari, Newcastle and Rzeszow having in their bus fleets many buses of EURO I and EURO II vehicle technologies could benefit the most with the use of either B20 or B80 blends. It is noted that due to insufficient data availability regarding the distribution of buses in the city of Copenhagen by EURO-norm, Copenhagen was not taken into consideration.

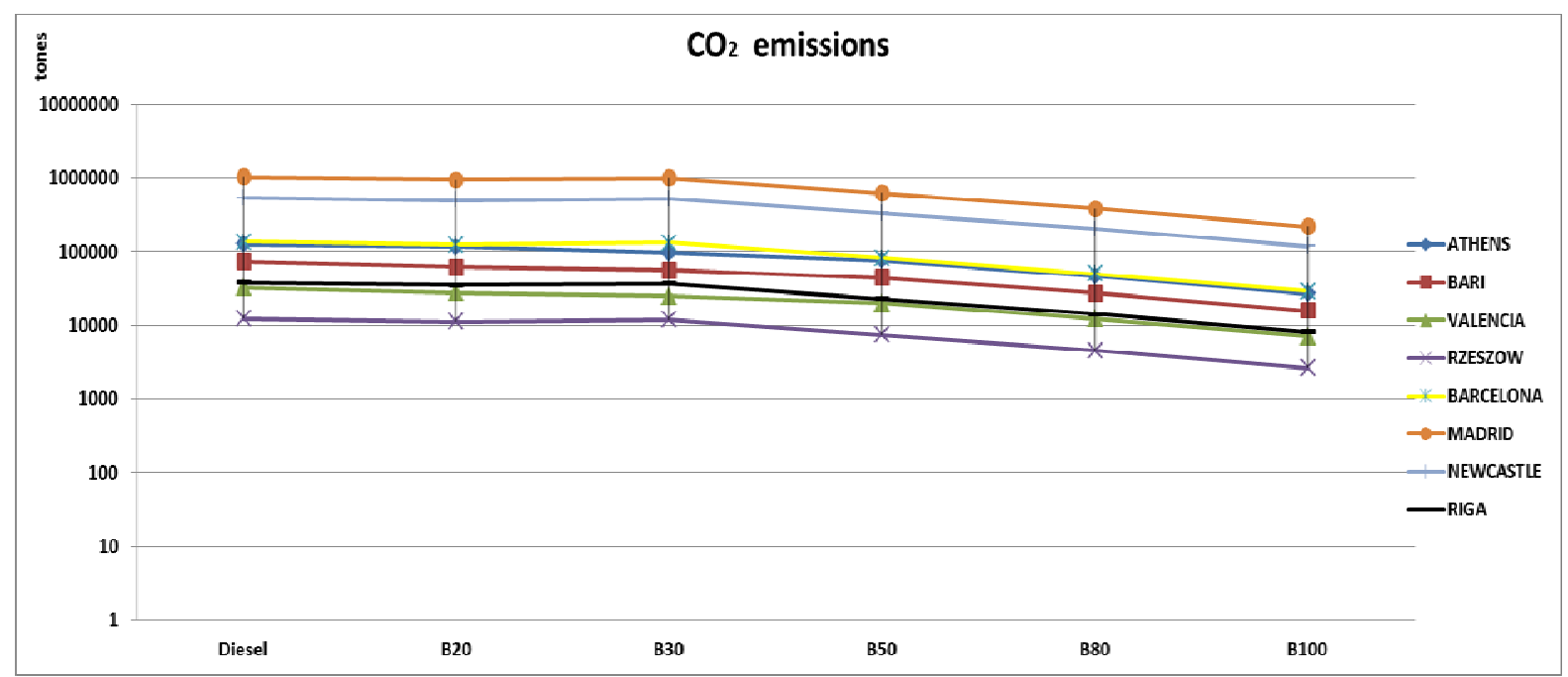

Fig 8. CO2 emissions for the different biodiesel blends - logarithmic scale

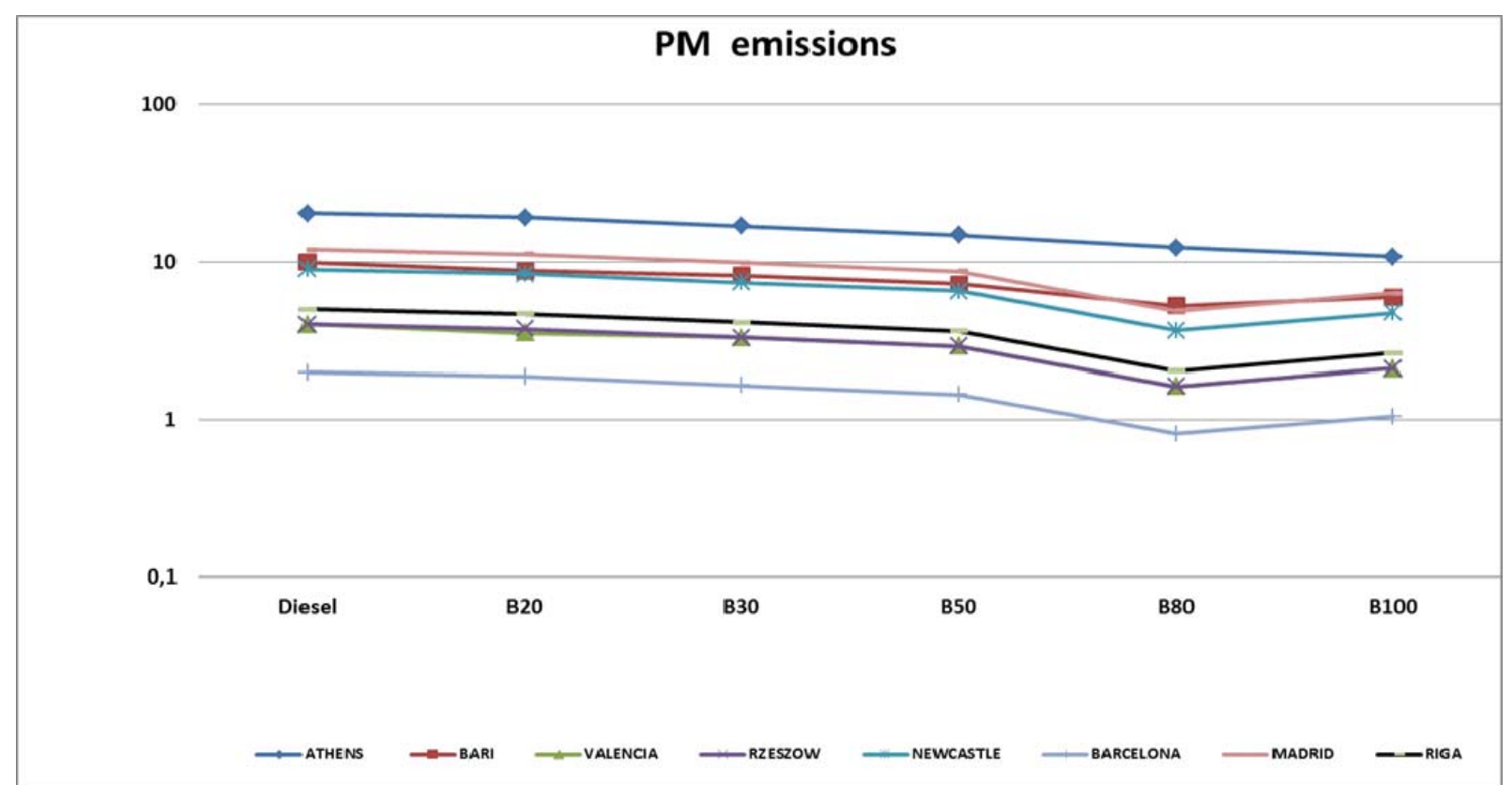

Fig 9. PM emissions for the different biodiesel blends-logarithmic scale

B20 seems to reduce CO by $10 \%$; whereas B100 to reduce CO by $48 \%$ (Fig. 10). The cities of Madrid, Barcelona and Newcastle could benefit the most from the use of biodiesel blend in their bus fleets. Additionally, B20 
seems to reduce unburned $\mathrm{HC} 10 \%$ in older engines; whereas the use of B100 seems to reduce $\mathrm{HC} 48 \%$. The cities of Madrid, Barcelona and Athens could benefit the most (Fig. 11).

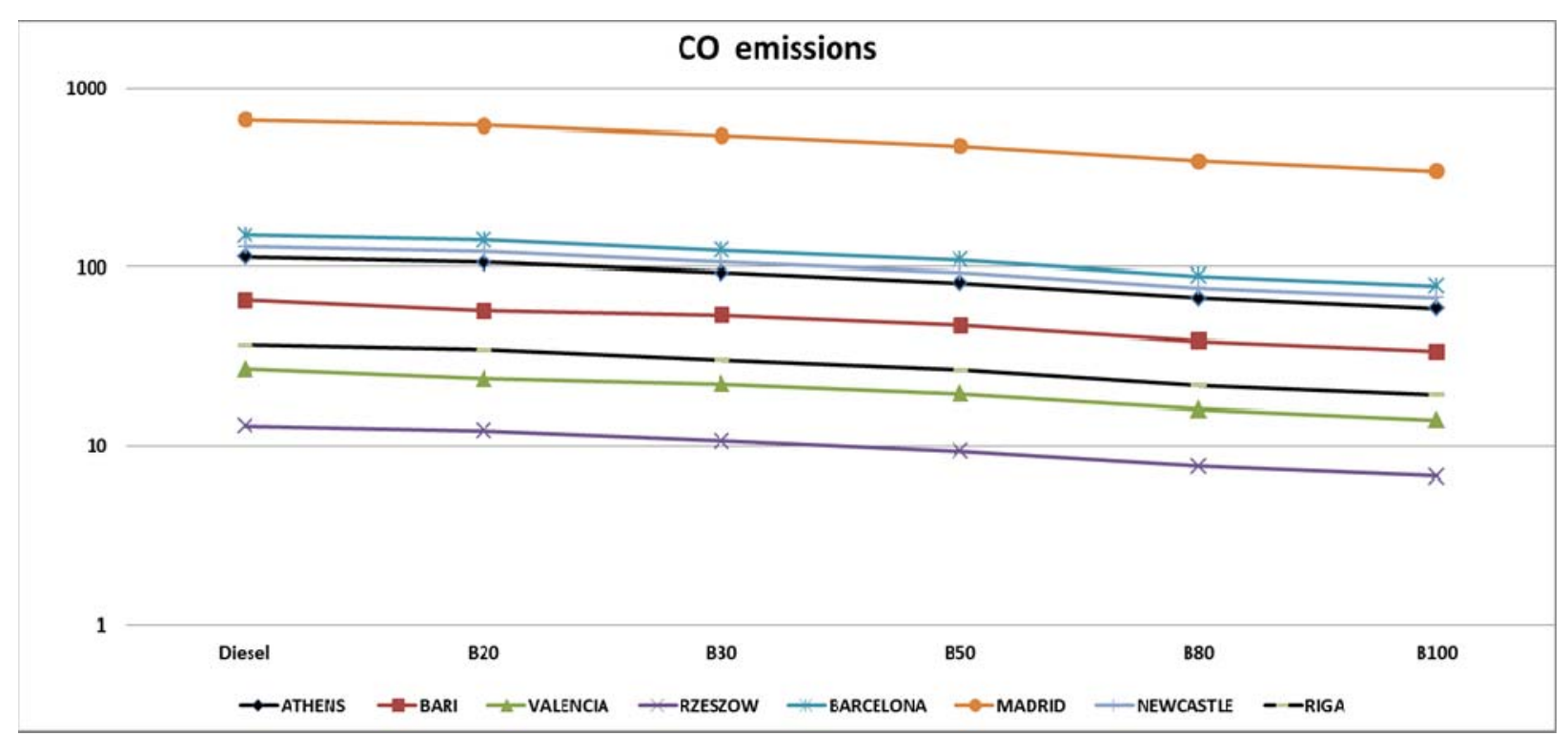

Fig 10. CO emissions for the different biodiesel blends

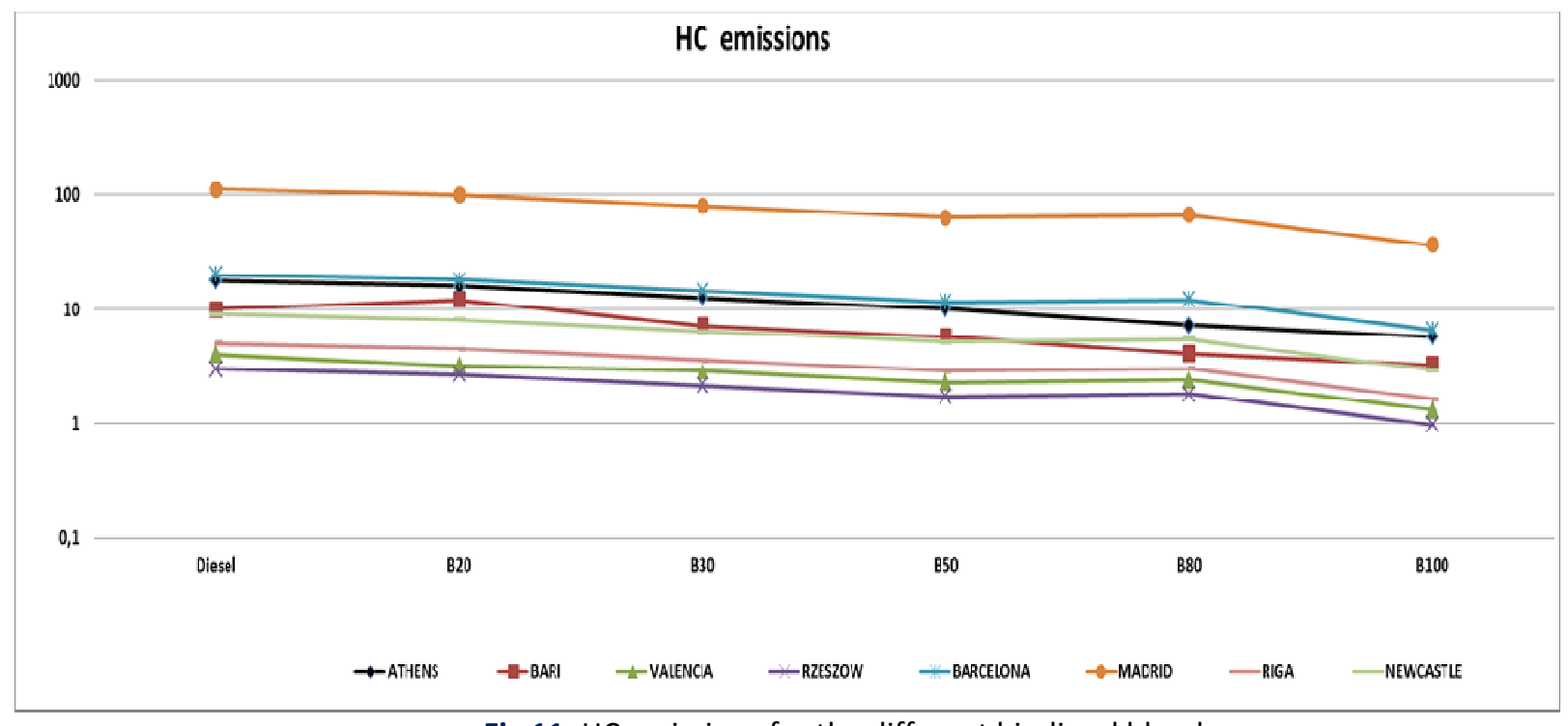

Fig 11. HC emissions for the different biodiesel blends

Finally, as far as the NOx emissions are concerned it is noted (Fig. 12) that these are increased as the percentages of biodiesel in the biodiesel mixes are increased (10.29\% increase in B100 blend compared to equivalent diesel emissions). 


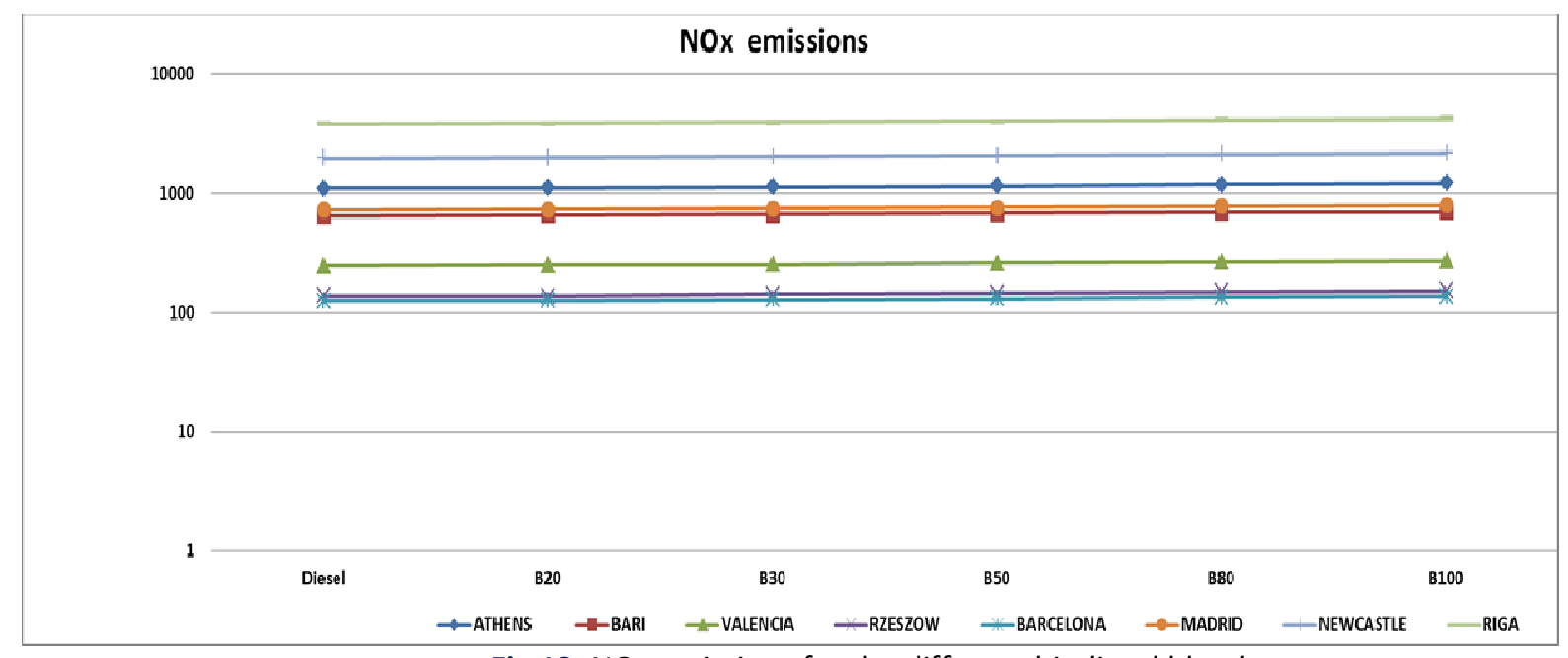

Fig 12. NOx emissions for the different biodiesel blends

It is noted that the abovementioned results of this study indicate that first generation biodiesel is beneficial with respect to the saving of fossil energy and to the greenhouse effect; nevertheless is detrimental regarding acidification, and eutrophication [41].

\section{Discussion}

Mobility plays a significant role both is economy and society, allowing people and goods to move around to where they can be profitably employed and also allows people to be able to maximise their opportunities and maintain their standards of living. Additionally, mobility has an environmental cost in terms of air pollution and damage to the natural environment as transport per passenger is related to energy consumption [42]. Most transport demand is positively correlated with GDP [43]. It can be assumed, that cascading financial and political crises will affect the public transportation systems of the cities under study. Some of the consequences of the financial crisis include the increase of fuel prices $(+50 \%)$, reduction of gross income $(25 \%$ $40 \%)$, increase of direct taxes, additional income and property taxes, increase of Value Added Tax ( 30\%) resulting in severe reduction of disposable income. The consequences on public transport include the reduction of state subsidy, resulting to increases in bus tickets. This is the case for example for the city of Athens where the urban bus tickets increased 25\% during the period of 2009 to 2011.

Increases in GDP could lead to decrease in bus fares as rising incomes could lead to higher car ownership, leading to a reduction in public bus demand. Changes in transport prices have an indirect impact on the environment due to the way in which transport demand responds to price signals. Changes in the price of a particular transport mode at first have relatively small effects as people have limited short-term options to adapt to the new situation. In the longer term, effects are greater as the options for behavioural adaptations increase. As an example, a rise in automotive fuel taxes may, over time, lead to a wide spectrum of reactions, such as a shift to public transport, increased car sharing, decreased car use, a transition to more fuel efficient cars and eventually reduced commuting distances due to relocation closer to work. Nevertheless Fig. 13 indicates a positive correlation between the cost of bus tickets and GDP in the cities under study, as the GDP increases the cost of bus tickets increases. Affordability is clearly an extremely important consideration for a sustainable public transportation system. National schemes should be implemented in order to provide subsidies to people on low incomes. 


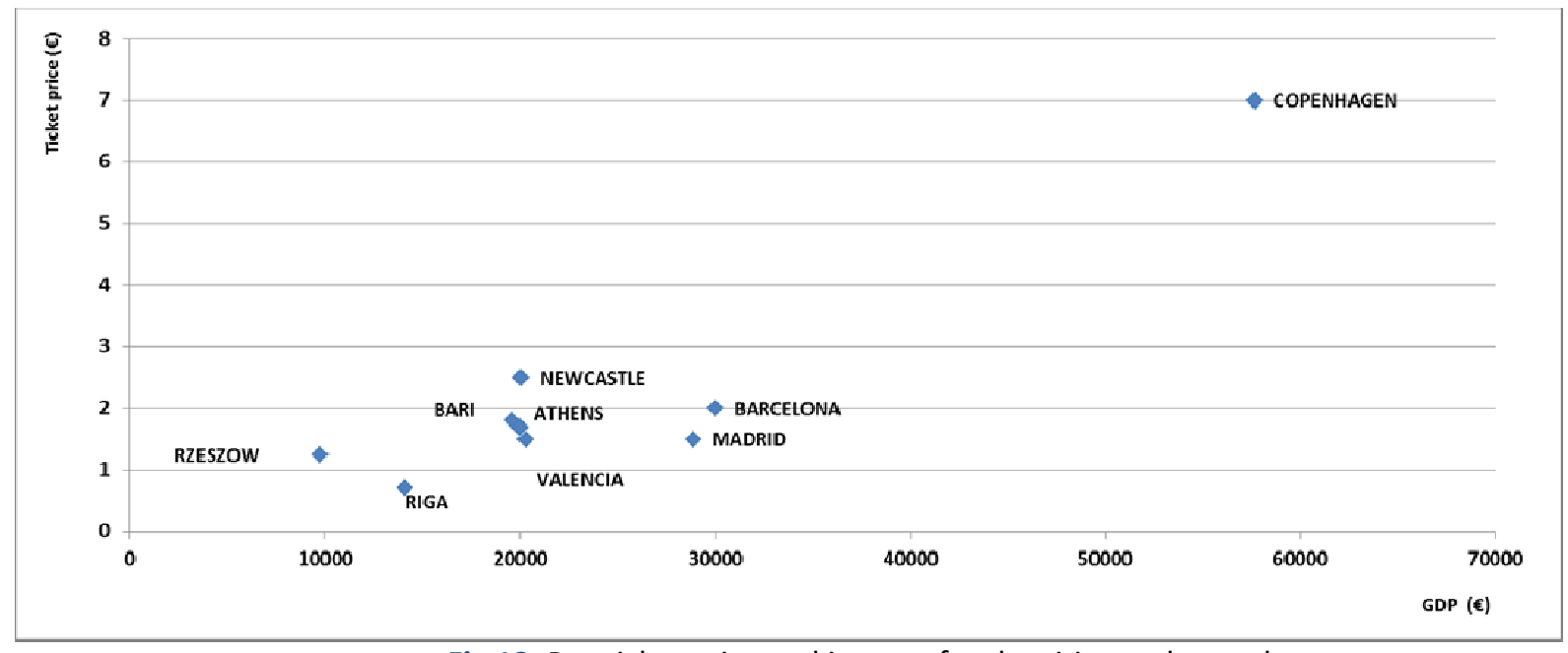

Fig 13. Bus ticket price and income for the cities under study

Fig. 14 illustrates the correlation between carbon emissions and population density. It is noticed that dense urban settlements are connected with lower per capita carbon emissions. This can be attributed to the fact that in dense urban settlements the services are concentrated, reducing by this way the need to travel large distances. In addition, in dense urban settlements the provision of public transportation networks is better.

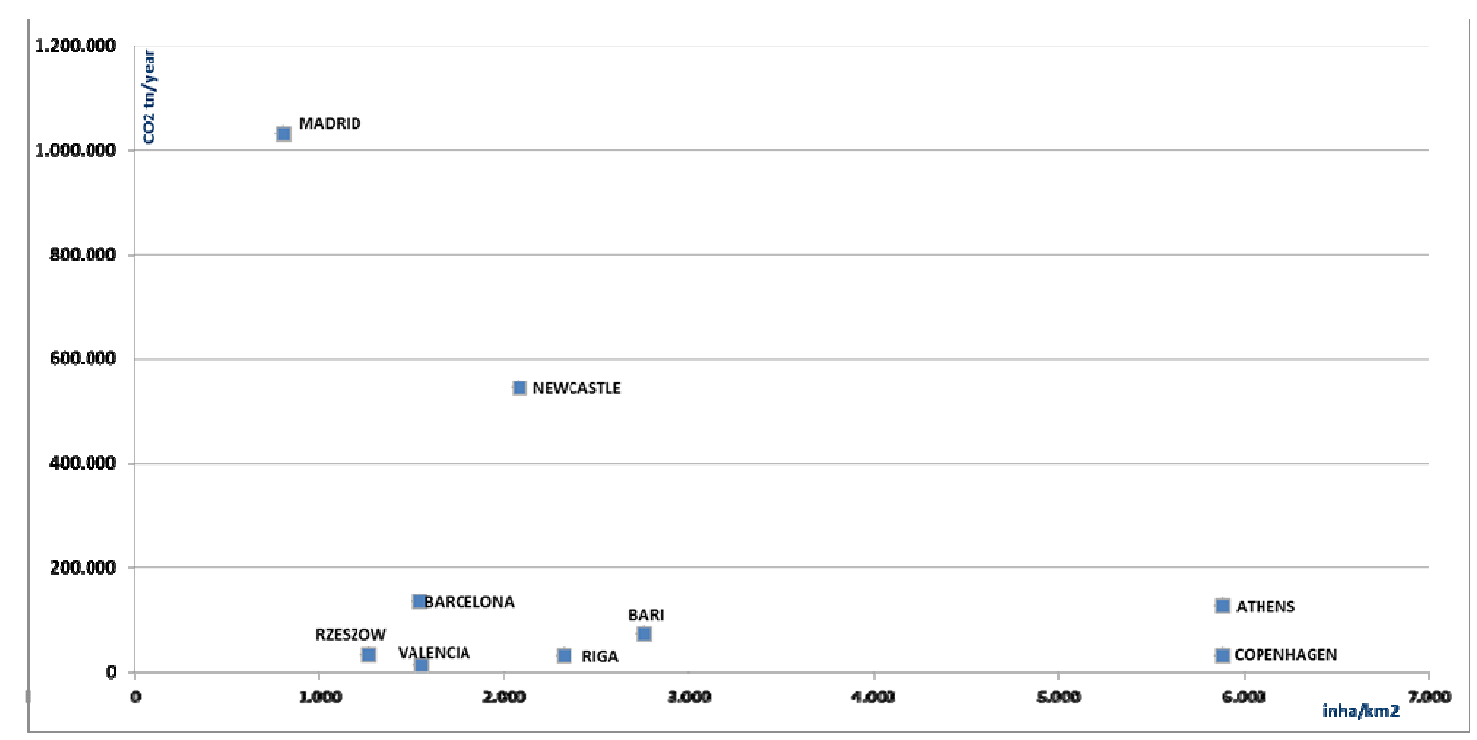

Fig 14. Carbon emissions and population density for the cities under study

Cities of different wealth levels have different environmental impacts. Differences in the levels of emissions coming from the different systems of each city depict differences in the quality and utilisation of bus networks. Carbon emissions are correlated to income. In general, per capita incomes are higher in cities resulting to higher average per capita demand in major emissions sources. Nonetheless this applies only to a certain income level, after which cities become more carbon-efficient compared with the average. Fig. 15, supports above argument as it illustrates the relatively low levels of $\mathrm{CO}_{2}$ emissions produced by high income cities like Copenhagen. The latter can also be attributed to the fact that two-third of all trips are done by walking and bicycling, and only $8 \%$ done by bus indicating that the share of bus trips in Copenhagen are lower than in most of the other cities under study. The cities of Riga and Rzeszow have a lower environmental impact compared to the cities of Newcastle and Barcelona, which they are characterized by significantly higher income levels (Fig. 15). 


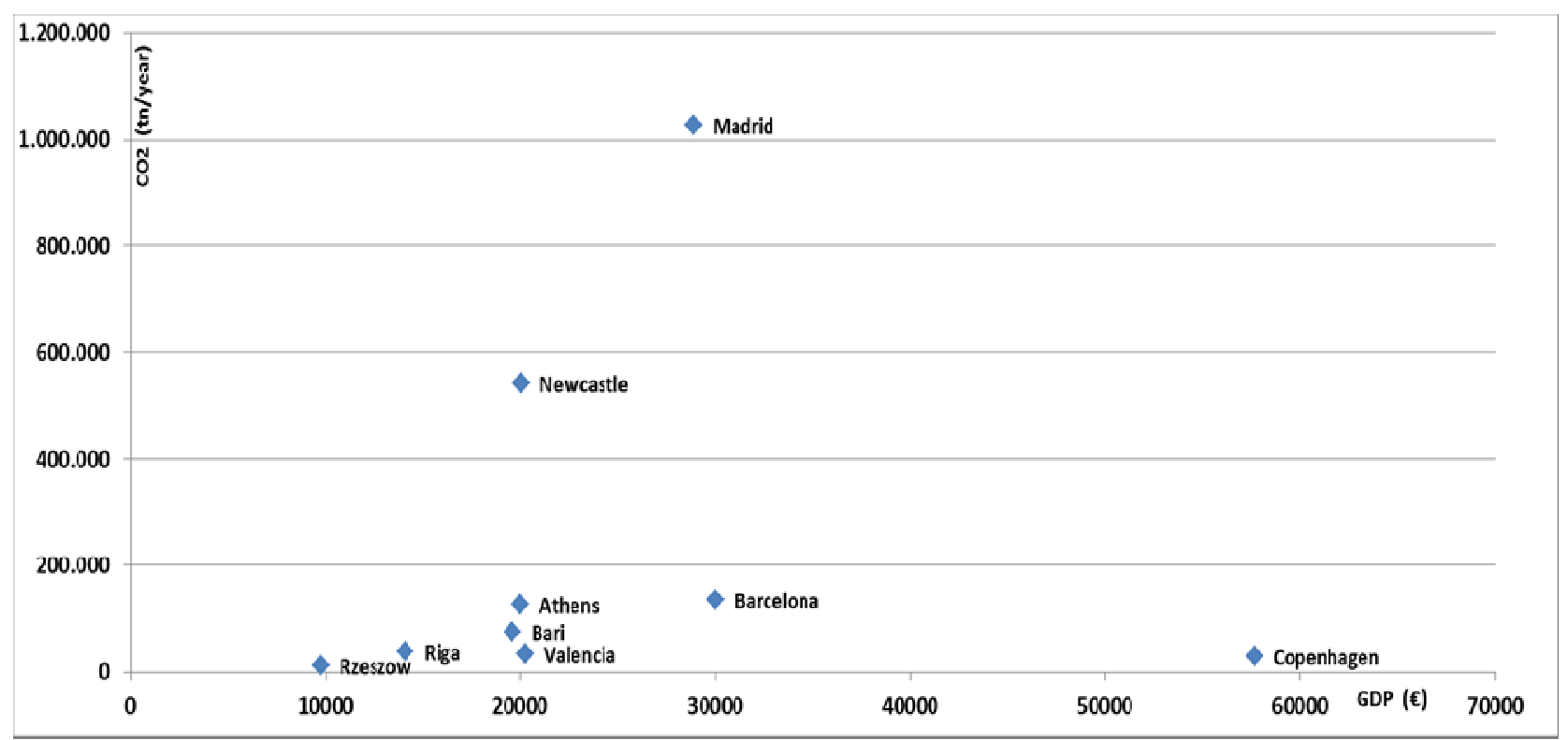

Fig 15. Carbon emissions and income for the cities under study

An efficient and flexible transport system is essential for a future low carbon transport system. In this context, an integrated approach should be ensured, so as to move towards a low carbon public transportation system. The different levels of emissions coming from each European's city's bus fleet point out differences in the size of cities as well as the length, bus fleet and utilization of the bus network. However, for all abovementioned systems it is noted that the use of alternative fuels for public transport- such as different blends of biofuels can reduce both local pollution and health inequality leading to low carbon transport system. Cities can expand and optimize public transportation in general promoting sustainable the use of alternative propulsion technologies. Further research is needed; in order to investigate the environmental impacts of the usage of different alternative fuels (biogas, bioethanol, etc), fuel cells as well as electricity to the European bus fleets under study. This research could help policy makers to take decisions regarding the creation of a low carbon public transportation system.

\section{Aknowledgments}

This work benefitted from support from the European Science Funded COST Action TU0902 "Integrated assessment technologies to support the sustainable development of urban areas".

\section{References}

1. OECD/IEA, 2005. Saving Oil in a Hurry. http://www.iea.org/textbase/nppdf/free/2005/SavingOil.pdf

2. European Environment Agency ( EEA). Report, No 3/2009 "Transport at a crossroads", TERM 2008: indicators tracking transport and environment in the European Union. Copenhagen, 2009

3. House of Commons (HOC) 2011; Environmental Audit Committee - Ninth Report Air quality: A follow up report; London; printed for Parliament on 26 October 2011.

http://www.publications.parliament.uk/pa/cm201012/cmselect/cmenvaud/1024/102402.htm 
4. Green Paper, 2007. Towards a New Culture for Urban Mobility, vol. 551. COM, Brussels. 23 p.

5. EC, 2011, White Paper 'Roadmap to a Single European Transport Area - Towards a competitive and resource efficient transport system' (COM(2011) 144 final of 28 March 2011) (http://eurlex.europa.eu/ LexUriServ/ LexUriServ.do?uri=COM:2011:0144:FIN:EN:PDF).

6. EC, 2011a, Communication from the Commission to the European Parliament, the Council, the European Economic and Social Committee and the Committee of the Regions 'A Roadmap for moving to a competitive low carbon economy in 2050' (COM(2011) 112 final of 8 March 2011) (http://eurlex.europa.eu/ LexUriServ/LexUriServ. do?uri=COM:2011:0112:FIN: EN:PDF).

7. Ally, J., Pryor, T., 2007. Life-cycle assessment of diesel, natural gas and hydrogen fuel cell bus transportation systems. Journal of Power Sources 170, 401-411.

8. Beer, T., Grant, T., Williams, D., Watsond, H., 2002. Fuel-cycle greenhouse gas emissions from alternative fuels in Australian heavy vehicles. Atmospheric Environment 36 (4), 753 e763.

9. Caulfield, B., Ryan, F., 2010. Examining the benefits of using bio-CNG in urban bus operations. Transport Research Part D 15 (6), 362e365.

10. Sheehan, J., Camobreco, V., Duffield, J., Graboski, M., Shapouri, H., 1998. Life Cycle Inventory of Biodiesel and Petroleum Diesel for Use in an Urban Bus. Report NREL/SR-580e24089. National Renewable Energy Laboratory. 284 p.

11. Oua, X., Zhang, X., Chang, S., 2010. Alternative fuel buses currently in use in China:life-cycle fossil energy use, GHG emissions and policy recommendations.Energy Policy 38 (1), $406 \mathrm{e} 418$.

12. L. Ntziachristos, Z. Samaras, EMEP/EEA emission inventory guidebook 2009, updated June 2010

13. T. Beer, T. Grant, G. Morgan, J, Lapszewicz, P. Anyon, J. Edwards, P. Nelson, H. Watson and D. Williams. "Life - cycle Emissions Analysis of Alternative Fuels for Heavy Vehicles", Australian Greenhouse Office, 2000.

14. N-O Nylund, K. Erkkilä, M. Lappi, M. Ikonen, M,. "Transit Bus Emission Study: Comparison of Emissions from Diesel and Natural Gas Buses; VTT Technical Research Centre of Finland"; Research Report. Project 3/P5150/04. 2004.

15. Autoritat de Transport Metropolita,Area de Barcelona, Report (2011)

16. Observatorio de la Movilidad Metropolitana (2012): Informe OMM-2010. Ministerio de Agricultura, Alimentación y Medio Ambiente, Madrid.

17. Ayuntament de Barcelona, Dades bàsiques de mobilitat 2011,Barcelona, (May 2012)

18. Comuni Italiani, 2012. Principali Città Regione Puglia. Retrieved on October 2012 from: http://www.comuni-italiani.it/16/lista.html

19. Azienda Mobilità e Trasporti Bari S.p.A., 2010. Carta della mobilità urbana. Retrieved on November 2011 from: http://www.amtabservizio.it

20. Source: Copenhagen Municipality, see: http://www.kk.dk/PolitikOgIndflydelse/Byudvikling/Byplanlaegning/Udviklingsplaner/Bylivsregnskab/ /media/E0309E4CBD604E59B2FE771E12065175.ashx

21. Region Hovedstaden (2009): Transportvaner i Hovedstadsregionen. Copehagen: Region Hovedstaden. Download: http://www.regionh.dk/NR/rdonlyres/AECCBC70-3A59-4964-962FEAC02224F1FA/0/Transportvanerihovedstadsregionen.pdf

22. ISPRA, 2012. Indicatori aree urbane. Retrieved on November 2012 from: http://www.areemetropolitane.sinanet.apat.it/Valori_temalist.php?pageno=1\&t=Valori_tema\&RecPer Page $=100$

23. EMT Valencia. http://www.emtvalencia.es/ciudadano/index.php

24. Ayuntamiento de Madrid (sin año): Futuro ciudad Madrid 2020. Proceso de reflexión estratégica. Ayuntamiento de Madrid, Madrid. Available in:http://www.madrid.es/UnidadesDescentralizadas/UDCObservEconomico/FuturoCiudadMadrid2020 /FUTUROCIUDADMADRID2020.pdf

25. Observatorio de la Movilidad Metropolitana (2012): Informe OMM-2010. Ministerio de Agricultura, Alimentación y Medio Ambiente, Madrid.

26. Consorcio Regional de Transportes de Madrid (CRTM) (2011): Informe Anual 2010. CRTM, Madrid. 
27. De Gregorio Hurtado, S. (2011): La stazione di interscambio di Principe Pío a Madrid. Presentation as key speaker in the Conference "I nodi di interscambio per il rilancio del trasporto pubblico in Piamonte". Regione Piamonte, 11st June, Turin.

28. Nexus (2010) Business Intelligence Annual Report-The Economic Paradox

29. Go North East (2012) Corporate Social Responsibility

30. DECC (2010) Road transport energy consumption at regional and local authority level, 2010

31. TW Integrated Transport Authority (2011) Keep Tyne and Wear Moving

32. Mobility Plan and Action Program for Riga and Pieriga. SEA Report. Latvia, Riga: Ministry of Transport, 2010.

33. A Resolution of the City Council of the City of Rzeszow No. XXVI 494 2012,"Zintegrowany plan rozwoju transportu publicznego Rzeszowa na lata 2010-2015", Rzeszów 2012, http://bip.erzeszow.pl

34. Baltic Biogas Bus "Feasibility study of introducing biogas buses in Rzeszow, Poland", Final report, 2012

35. Oficyna Wydawnicza Politechniki Warszawskiej, Warszawa 2001.

36. E. A. Nanaki, C. J. Koroneos, E. Konstantinidis (2013). "Evironmental assessment of urban buses- diesel, cng and biofuel powered", 3rd International Exergy, Life Cycle Assessment, and Sustainability Workshop \& Symposium (ELCAS3) 07 -09 July, 2013, NISYROS - GREECE, NISYROS - GREECE; 07/2013.

37. K.S. Crump, T. Lampert, C. Chen, "Assessment of Risk from Exposure to Diesel Engine Emissions", 6802-4601-56; Prepared for U.S. Environmental Protection Agency, Office of Health Assessment, Washington, DC, by Clement International Corporation, 1991.

38. K.S. Crump, "Lung Cancer Mortality and Diesel Exhaust: Reanalysis of a Retrospective Cohort Study of U.S. Railroad Workers" Inhal. Toxicol, 11 (1999), 1-17.

39. H.E. Wichmann, C. Spix, T. Tuch, G. Wölke, A. Peters, J. Heinrich, W.G. Kreyling, J. Heyder, "Daily Mortality and Fine and Ultrafine Particles in Erfurt, Germany-Part I, Role of Particle Number and Particle Mass", HEI Research Report No 98 (2000) Health Effects Institute: Cambridge, MA.

40. Environmental Protection Agency -EPA, "Health Assessment Document for Diesel Engine Exhaust", National Center for Environmental Assessment, Office of Research and Development, Washington DC, 2002.

41. Evanthia A Nanaki, Christopher J Koroneos. (2012)"Comparative LCA of the use of biodiesel, diesel and gasoline for transportation", Journal of Cleaner Production .01/2012; 20(1):14-19. DOI:http://dx.doi.org/10.1016/j.jclepro.2011.07.026

42. C. Koroneos, E. Nanaki. "Measuring Greece's progress towards energy sustainability". International Journal of Global Energy Issues 02/2007; 27(1):77-101. DOI:10.1504/IJGEI.2007.012119

43. C. Koroneos, E. Nanaki. (2007) "Environmental assessment of the Greek transport sector". Energy Policy 02/2007; 35(11):5422-5432. DOI:10.1016/j.enpol.2007.05.005 